Published in final edited form as:

J Am Chem Soc. 2015 December 02; 137(47): 14838-14841. doi:10.1021/jacs.5b09711.

\title{
DNA-Mediated Cellular Delivery of Functional Enzymes
}

\author{
Jeffrey D. Brodin ${ }^{\dagger, \ddagger, \|}$, Anthony J. Sprangers ${ }^{\dagger, \S, \|}$, Janet R. McMillan ${ }^{\dagger, \ddagger}$, and Chad A. \\ Mirkin ${ }^{\star}, \dagger, \ddagger, \S$ \\ †International Institute of Nanotechnology, Northwestern University, 2145 Sheridan Road, \\ Evanston, Illinois 60208, United States \\ ‡Department of Chemistry, Northwestern University, 2145 Sheridan Road, Evanston, Illinois \\ 60208, United States
}

$\S$ Department of Biomedical Engineering, Northwestern University, 2145 Sheridan Road, Evanston, Illinois 60208, United States

\begin{abstract}
We report a strategy for creating a new class of protein transfection materials composed of a functional protein core chemically modified with a dense shell of oligonucleotides. These materials retain the native structure and catalytic ability of the hydrolytic enzyme $\beta$-galactosidase, which serves as the protein core, despite the functionalization of its surface with $\sim 25$ DNA strands. The covalent attachment of a shell of oligonucleotides to the surface of $\beta$-galactosidase enhances its cellular uptake of by up to $\sim 280$-fold and allows for the use of working concentrations as low as $100 \mathrm{pM}$ enzyme. DNA-functionalized $\beta$-galactosidase retains its ability to catalyze the hydrolysis of $\beta$-glycosidic linkages once endocytosed, whereas equal concentrations of protein show little to no intracellular catalytic activity.
\end{abstract}

Proteins represent a highly evolved class of natural nanoparticles with an unparalleled degree of structural and compositional homogeneity, as well as diversity of functional applications. ${ }^{1}$ In particular, the efficient intracellular delivery of functional proteins has widespread applications in medicine ${ }^{2-5}$ and provides a means for engineering cellular functions. However, the cellular uptake of functional proteins is impeded by their inherent instability, large sizes, and charged surfaces..$^{5}$ To address these limitations, a variety of approaches have been developed for stabilizing proteins and enhancing their cellular uptake, which include covalent ${ }^{6-10}$ or noncovalent ${ }^{11}$ attachment of polymers, ${ }^{12}$ conjugation to cellpenetrating peptides, ${ }^{13-17}$ formulation with lipids, ${ }^{18}$ liposomes,${ }^{19}$ or nanoparticles,,${ }^{4,20-22}$ and attachment to highly charged natural ${ }^{23}$ or engineered proteins. ${ }^{24,25}$ While each of these strategies has unique attributes, they often require incubation of cells with relatively high

\footnotetext{
*Corresponding Author: chadnano@northwestern.edu.

These authors contributed equally.

Supporting Information

The Supporting Information is available free of charge on the ACS Publications website at DOI: 10.1021/jacs.5b09711.

Methods and Figures S1-S11 (PDF)

Notes

The authors declare no competing financial interest.
} 
protein concentrations and in many cases result in formulations with poorly defined compositions or limited stabilities.

Recently, spherical nucleic acid (SNA)-nanoparticle conjugates, ${ }^{26}$ which consist of a nanoparticle core surrounded by a dense shell of oligonucleotides, ${ }^{27}$ have emerged as exciting new architectures with diverse biological applications in gene regulation, ${ }^{28}$ immunomodulation, ${ }^{29}$ and intracellular detection. ${ }^{30,31}$ These applications are possible due to the superior cellular uptake ${ }^{32,33}$ and physiological stability ${ }^{34}$ of SNAs relative to their individual components. This enhanced cellular internalization of SNAs is derived from the 3-D architecture of the conjugates and its ability to engage scavenger receptors on the surfaces of most cells. ${ }^{32,35}$ Importantly, the favorable biological properties of SNAs are independent of their nanoparticle cores, ${ }^{36-39}$ which can therefore be chosen based on potential biological applications rather than practical synthetic limitations. Based on these observations, we hypothesized that proteins could serve as the nanoparticle core of SNAs and the dense shell of oligonucleotides as a biocompatible polymer shell that promotes cellular uptake. These supramolecular structures, termed ProSNAs (Figure 1A), are distinct from previous examples of protein-DNA conjugates that contain only a few conjugated oligonucleotides ${ }^{41,42}$ and lack protein-based functionalities, those based on virus capsids, ${ }^{43}$ or those that employ the attached oligonucleotides as a polyanionic structure to which cationic polymers noncovalently associate, ${ }^{11}$ but that alone are ineffective in promoting cellular uptake.

In contrast to more traditional nanoparticles, proteins are characterized by surfaces with a nonuniform distribution of chemically reactive sites and core structures that are held together by a complex network of relatively weak interactions. An essential consideration for the implementation of our approach is therefore whether a dense shell of oligonucleotides can be conjugated to the surface of a protein while retaining its native structure and catalytic functionality. To demonstrate that this is the case, the large (464 kDa) homotetrameric enzyme $\beta$-galactosidase $(\beta \text {-gal) (Figure 1A, (1) })^{40}$ was chosen as a model system. Due to its large size $(17.5 \times 14 \times 8.5 \mathrm{~nm}), \beta$-gal does not efficiently traverse cellular membranes and has therefore served as an ideal model system for testing the feasibility of various strategies for the intracellular delivery of functional enzymes. ${ }^{7}, 13,15,16,18,20,44$ Additionally, $\beta$-gal catalyzes the hydrolysis of $\beta$-glycosidic bonds between galactose and a diverse range of organic moieties, allowing one to determine the effects of substrate size and chemical composition on catalysis.

The surface of $\beta$-gal was modified with fluorophores to allow quantification of the protein concentration after modification with oligonucleotides and to provide a handle for monitoring cellular uptake via flow cytometry and confocal microscopy (vida infra). Addition of a 5-fold excess of a thiol-reactive fluorochrome (AF647 maleimide, Figure 1B, i) yielded a tetramer with $\sim 4$ fluorophore modifications $\left(\mathrm{AF}_{4}-\beta\right.$-gal $)$, as determined by $\mathrm{UV}-$ vis absorbance spectroscopy (Figure $2 \mathrm{~A}$ ). The surface of $\mathrm{AF}_{4}-\beta$-gal was then functionalized with DNA essentially as previously described. ${ }^{45}$ Briefly, surface lysine amines were reacted with small polyethylene glycol (PEG) polymers with an azide and an amine-reactive $\mathrm{N}$ hydroxy succinimide moiety (Figure 1B, ii) at opposing termini. The covalently attached azides were then reacted with DNA strands containing the strained cyclooctyne, 
dibenzocyclooctyne (DBCO) at the $5^{\prime}$-terminus via copper-free click chemistry (Figure 1B, iii). The sequence used here (dGGT) 10 was chosen based on previous work that showed enhanced cellular uptake of SNAs with G-rich shells relative to poly dT shells. ${ }^{33}$ This strategy yielded the conjugate ProSNA $\beta$-gal (Figure 1A, (2)), with $25 \pm 1$ strands of DNA per tetrameric enzyme. The level of DNA modification was determined by comparing the difference in absorbance at $260 \mathrm{~nm}$ between $\mathrm{AF}_{4}-\beta$-gal and ProSNA $\beta$-gal (Figure $2 \mathrm{~A}$ ). Agarose gel electrophoresis of ProSNA $\beta$-gal showed an increase in its electrophoretic mobility relative to $\mathrm{AF}_{4} \beta$-gal due to the introduction of a large number of negatively charged phosphate groups within the DNA shell (Figure S2). An additional staining step for DNA revealed that the protein and DNA ran with the same electrophoretic mobility for ProSNA $\beta$-gal, whereas a mixture of $\mathrm{AF}_{4}-\beta$-gal and free DNA ran as two distinct bands, demonstrating the covalent attachment of oligonucleotides rather than nonspecific association with its surface.

Circular dichroism spectroscopy was employed to determine whether the $\beta$-gal that composes the ProSNA core retains its native structure, which is essential for preserving its catalytic functionality. As shown in Figure 2B, the observed spectrum of ProSNA $\beta$-gal agrees well with a theoretical spectrum obtained by summing the spectra of $\mathrm{AF}_{4}-\beta$-gal and an equivalent concentration of the free oligonucleotides. This agreement indicates that the enzyme retains its secondary structure after attachment of a shell of oligonucleotides. To determine whether the attached oligonucleotides provide a steric barrier to or alter the enzyme active site and impair its catalytic functionality, we performed a fluorescence assay utilizing the substrate, 7-hydroxycoumarin-3-carboxylic acid (CUG) (Figure 2C,D), which releases a fluorescent coumarin derivative upon hydrolysis of the $\beta$-glycosidic linkage with galactose. Despite the high degree of surface modification of the protein and the relatively large size of the CUG substrate, ProSNA $\beta$-gal retained catalytic activity at all enzyme concentrations tested.

We next tested whether ProSNA $\beta$-gal shows enhanced cellular uptake relative to $\mathrm{AF}_{4}-\beta$-gal in multiple mammalian cell lines (HaCaT, human keratinocytes; C166, mouse epithelial cells; and SKOV3, human ovarian adenocarcinoma cells). Cells were incubated with 0.1 or 1 $\mathrm{nM}$ protein for $1.5-12 \mathrm{~h}$, and their uptake was determined by flow cytometry (Figures 3 and $\mathrm{S} 3$ ). Compared to cells incubated with $\mathrm{AF}_{4}-\beta$-gal, ProSNA $\beta$-gal showed an $\sim 20-280$-fold increase in cellular uptake. At the lowest concentration tested $(0.1 \mathrm{nM})$, ProSNA $\beta$-gal showed nearly 2 orders of magnitude greater cellular uptake than $\mathrm{AF}_{4}-\beta$-gal. We have previously shown that the route for enhancements in the cellular uptake of conventional SNA conjugates involves engagement of cell-surface scavenger receptors followed by caveolae-mediated endocytosis. ${ }^{32,35}$ To evaluate whether ProSNA $\beta$-gal is uptaken by a similar mechanism, cells were treated with fucoidan, a scavenger receptor ligand, after which cellular uptake of ProSNA $\beta$-gal was monitored by flow cytometry. As shown in Figure S4, treatment with fucoidan resulted in an $80-90 \%$ decrease in the cellular uptake of ProSNA $\beta$-gal, which is consistent with the conclusion that it is internalized by a similar mechanism as traditional SNA conjugates. Importantly, ProSNA $\beta$-gal showed no apparent toxicity toward any of the cell lines tested here, as demonstrated by measuring cellular metabolic redox activity using the commonly employed cell viability indicator resazurin (Figure S5). 
To ensure that the transfected enzymes remained functional within the cellular milieu, we employed two catalytic assays based on distinct substrates. For both assays, HaCaT, SKOV3, and $\mathrm{C} 166$ cells were incubated with $1 \mathrm{nM} \mathrm{AF}_{4}$ - or ProSNA $\beta$-gal for $12 \mathrm{~h}$. After washing the cells with phosphate buffered saline (PBS) to remove any enzyme bound to the cell surface, a $1 \mathrm{mg} \mathrm{mL}^{-1}$ solution of the membrane permeable $\beta$-gal substrate 5-bromo-4-chloro-3indolyl- $\beta$-D-galactopyranoside (Xgal, Figure S6) was added, and the cells were incubated for $3 \mathrm{~h}$ at $37^{\circ} \mathrm{C}$. Hydrolysis of the $\beta$-glycosidic linkage of Xgal results in the release of an indole derivative that, upon oxidation, dimerizes and forms an insoluble blue precipitate that can be visualized by light microscopy (Figure S6A). As shown in Figure 4A, essentially all cells treated with $1 \mathrm{nM}$ ProSNA $\beta$-gal showed accumulation of the blue product throughout the entire cell volume, demonstrating that the transfected protein remains active intracellularly. In the case of $\mathrm{HaCaT}$ cells, ProSNA $\beta$-gal treatments as low as $0.1 \mathrm{nM}$ still produced a visible response (Figure S7). In contrast, untreated cells or cells treated with up to $10 \mathrm{nM} \mathrm{AF}_{4}-\beta$-gal showed minimal substrate hydrolysis, demonstrating that product formation is catalyzed by transfected enzymes and not endogenous $\beta$-gal and that the shell of DNA is necessary for cellular uptake of functional enzymes (Figure S8).

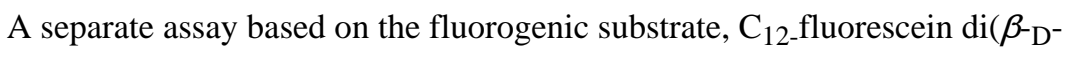
galactopyranoside) $\left(\mathrm{C}_{12}\right.$-FDG, Figure $\left.\mathrm{S} 6 \mathrm{~B}\right)$, was used to further demonstrate that catalysis originates from transfected $\beta$-gal. $\mathrm{C}_{12}$-FDG is not fluorescent, but upon hydrolysis of the glycosidic bonds between fluorescein and galactose produces a fluorescent signal upon excitation by $488 \mathrm{~nm}$ light. This assay allows for simultaneous visualization of the cellular uptake of native or ProSNA $\beta$-gal and the reaction product, $\mathrm{C}_{12}$-fluorescein. Cells were transfected with either $1 \mathrm{nM} \mathrm{AF}_{4}$ - or ProSNA $\beta$-gal and then incubated with $\mathrm{C}_{12}$-FDG for 1 $\mathrm{h}$ at $37^{\circ} \mathrm{C}$, washed, and examined by confocal fluorescence microscopy for intracellular fluorescence (Figures 4B and S9-10). For the ProSNA, both the enzyme (AF647 channel) and $\mathrm{C}_{12}$-FDG reaction product (FITC channel) were observed within the cells at $1 \mathrm{nM}$ treatments (Figure S11). Conversely, cells treated with the native enzyme exhibited no signal for either the product or the enzyme.

In conclusion, we have developed a chemical strategy for transforming cell membraneimpermeable proteins into ProSNAs that enter cells at low concentrations. The results presented here show that these architectures are highly uptaken by cells and function as intracellular enzymes. This work is an initial proof-of-concept that lays the foundation for creating a new class of biologically active materials from a nearly limitless library of protein nanoparticles that can serve as the ProSNA core. Future design iterations will allow tuning of both the DNA shell, which compared to other polymers is highly monodisperse and sequence specific, as well as the protein core, which presents multiple orthogonal functional groups on its surface that should allow for the attachment of several distinct functionalities such as imaging agents, targeting moieties, and functional oligonucleotides.

\section{Supplementary Material}

Refer to Web version on PubMed Central for supplementary material. 


\section{Acknowledgments}

This material is based upon work supported by the Department of Defense National Security Science and Engineering Faculty Fellowship award N00014-15-1-0043; the Center for Cancer Nanotechnology Excellence initiative of the National Institutes of Health under award U54 CA151880; and the NTU-NU Institute for NanoMedicine located at the Intl. Inst. for Nanotechnology, Northwestern University, U.S.A. and the Nanyang Technological University, Singapore. A.J.S. acknowledges a National Science Foundation Graduate Research Fellowship. Bright-field microscopy was conducted at the Biological Imaging Facility at Northwestern University.

\section{References}

1. Mann S. Angew Chem, Int Ed. 2008; 47:5306.

2. Torchilin V. Drug Discovery Today: Technol. 2008; 5:e95.

3. Petros RA, DeSimone JM. Nat Rev Drug Discovery. 2010; 9:615. [PubMed: 20616808]

4. Gu Z, Biswas A, Zhao M, Tang Y. Chem Soc Rev. 2011; 40:3638. [PubMed: 21566806]

5. Fu A, Tang R, Hardie J, Farkas ME, Rotello VM. Bioconjugate Chem. 2014; 25:1602.

6. Yan M, Du J, Gu Z, Liang M, Hu Y, Zhang W, Priceman S, Wu L, Zhou ZH, Liu Z. Nat Nanotechnol. 2010; 5:48. [PubMed: 19935648]

7. Kuan SL, Ng DY, Wu Y, Förtsch C, Barth H, Doroshenko M, Koynov K, Meier C, Weil T. J Am Chem Soc. 2013; 135:17254. [PubMed: 24156787]

8. Pelegri-O’Day EM, Lin E-W, Maynard HD. J Am Chem Soc. 2014; 136:14323. [PubMed: 25216406]

9. Fuhrmann G, Grotzky A, Lukić R, Matoori S, Luciani P, Yu H, Zhang B, Walde P, Schlüter AD, Gauthier MA. Nat Chem. 2013; 5:582. [PubMed: 23787748]

10. Nguyen TH, Kim S-H, Decker CG, Wong DY, Loo JA, Maynard HD. Nat Chem. 2013; 5:221. [PubMed: 23422564]

11. Eltoukhy AA, Chen D, Veiseh O, Pelet JM, Yin H, Dong Y, Anderson DG. Biomaterials. 2014; 35:6454. [PubMed: 24831975]

12. Wu Y, Ng DY, Kuan SL, Weil T. Biomater Sci. 2015; 3:214. [PubMed: 26218113]

13. Fawell S, Seery J, Daikh Y, Moore C, Chen LL, Pepinsky B, Barsoum J. Proc Natl Acad Sci U S A. 1994; 91:664. [PubMed: 8290579]

14. Fuchs SM, Raines RT. Protein Sci. 2005; 14:1538. [PubMed: 15930002]

15. Rodrigues M, de la Torre BG, Rádis-Baptista G, Santos NC, Andreu D. Bioconjugate Chem. 2011; 22:2339.

16. Schwarze SR, Ho A, Vocero-Akbani A, Dowdy SF. Science. 1999; 285:1569. [PubMed: 10477521]

17. Morris MC, Depollier J, Mery J, Heitz F, Divita G. Nat Biotechnol. 2001; 19:1173. [PubMed: 11731788]

18. Zelphati O, Wang Y, Kitada S, Reed JC, Felgner PL, Corbeil J. J Biol Chem. 2001; 276:35103. [PubMed: 11447231]

19. Xu X, Costa A, Burgess DJ. Pharm Res. 2012; 29:1919. [PubMed: 22403024]

20. Ghosh P, Yang X, Arvizo R, Zhu Z-J, Agasti SS, Mo Z, Rotello VM. J Am Chem Soc. 2010; 132:2642. [PubMed: 20131834]

21. Tang R, Kim CS, Solfiell DJ, Rana S, Mout R, Velázquez-Delgado EM, Chompoosor A, Jeong Y, Yan B, Zhu Z-J. ACS Nano. 2013; 7:6667. [PubMed: 23815280]

22. Shah DA, Kwon S-J, Bale SS, Banerjee A, Dordick JS, Kane RS. Biomaterials. 2011; 32:3210. [PubMed: 21296414]

23. Cronican JJ, Beier KT, Davis TN, Tseng J-C, Li W, Thompson DB, Shih AF, May EM, Cepko CL, Kung AL. Chem Biol. 2011; 18:833. [PubMed: 21802004]

24. Lawrence MS, Phillips KJ, Liu DR. J Am Chem Soc. 2007; 129:10110. [PubMed: 17665911]

25. Cronican JJ, Thompson DB, Beier KT, McNaughton BR, Cepko CL, Liu DR. ACS Chem Biol. 2010; 5:747. [PubMed: 20545362]

26. Cutler JI, Auyeung E, Mirkin CA. J Am Chem Soc. 2012; 134:1376. [PubMed: 22229439]

27. Mirkin CA, Letsinger RL, Mucic RC, Storhoff JJ. Nature. 1996; 382:607. [PubMed: 8757129]

J Am Chem Soc. Author manuscript; available in PMC 2018 March 01. 
28. Rosi NL, Giljohann DA, Thaxton CS, Lytton-Jean AK, Han MS, Mirkin CA. Science. 2006; 312:1027. [PubMed: 16709779]

29. Radovic-Moreno AF, Chernyak N, Mader CC, Nallagatla S, Kang RS, Hao L, Walker DA, Halo TL, Merkel TJ, Rische CH. Proc Natl Acad Sci U S A. 2015; 112:3892. [PubMed: 25775582]

30. Zheng D, Seferos DS, Giljohann DA, Patel PC, Mirkin CA. Nano Lett. 2009; 9:3258. [PubMed: 19645478]

31. Seferos DS, Giljohann DA, Hill HD, Prigodich AE, Mirkin CA. J Am Chem Soc. 2007; 129:15477. [PubMed: 18034495]

32. Choi CHJ, Hao L, Narayan SP, Auyeung E, Mirkin CA. Proc Natl Acad Sci U S A. 2013; 110:7625. [PubMed: 23613589]

33. Narayan SP, Choi CHJ, Hao L, Calabrese CM, Auyeung E, Zhang C, Goor OJ, Mirkin CA. Small. 2015; 11:4173-4182. [PubMed: 26097111]

34. Seferos DS, Prigodich AE, Giljohann DA, Patel PC, Mirkin CA. Nano Lett. 2009; 9:308. [PubMed: 19099465]

35. Patel PC, Giljohann DA, Daniel WL, Zheng D, Prigodich AE, Mirkin CA. Bioconjugate Chem. 2010; 21:2250.

36. Cutler JI, Zhang K, Zheng D, Auyeung E, Prigodich AE, Mirkin CA. J Am Chem Soc. 2011; 133:9254. [PubMed: 21630678]

37. Cutler JI, Zheng D, Xu X, Giljohann DA, Mirkin CA. Nano Lett. 2010; 10:1477. [PubMed: 20307079]

38. Young KL, Scott AW, Hao L, Mirkin SE, Liu G, Mirkin CA. Nano Lett. 2012; 12:3867. [PubMed: 22725653]

39. Banga RJ, Chernyak N, Narayan SP, Nguyen ST, Mirkin CA. J Am Chem Soc. 2014; 136:9866. [PubMed: 24983505]

40. Jacobson R, Zhang X-J, DuBose R, Matthews B. Nature. 1994; 369:761-766. [PubMed: 8008071]

41. Kostiainen MA, Szilvay GR, Lehtinen J, Smith DK, Linder MB, Urtti A, Ikkala O. ACS Nano. 2007; 1:103. [PubMed: 19206526]

42. Cho HJ, Takabayashi K, Cheng PM, Nguyen MD, Corr M, Tuck S, Raz E. Nat Biotechnol. 2000; 18:509. [PubMed: 10802617]

43. Tong GJ, Hsiao SC, Carrico ZM, Francis MB. J Am Chem Soc. 2009; 131:11174. [PubMed: 19603808]

44. Hasadsri L, Kreuter J, Hattori H, Iwasaki T, George JM. J Biol Chem. 2009; 284:6972. [PubMed: 19129199]

45. Brodin JD, Auyeung E, Mirkin CA. Proc Natl Acad Sci U S A. 2015; 112:4564. [PubMed: 25831510]

J Am Chem Soc. Author manuscript; available in PMC 2018 March 01. 

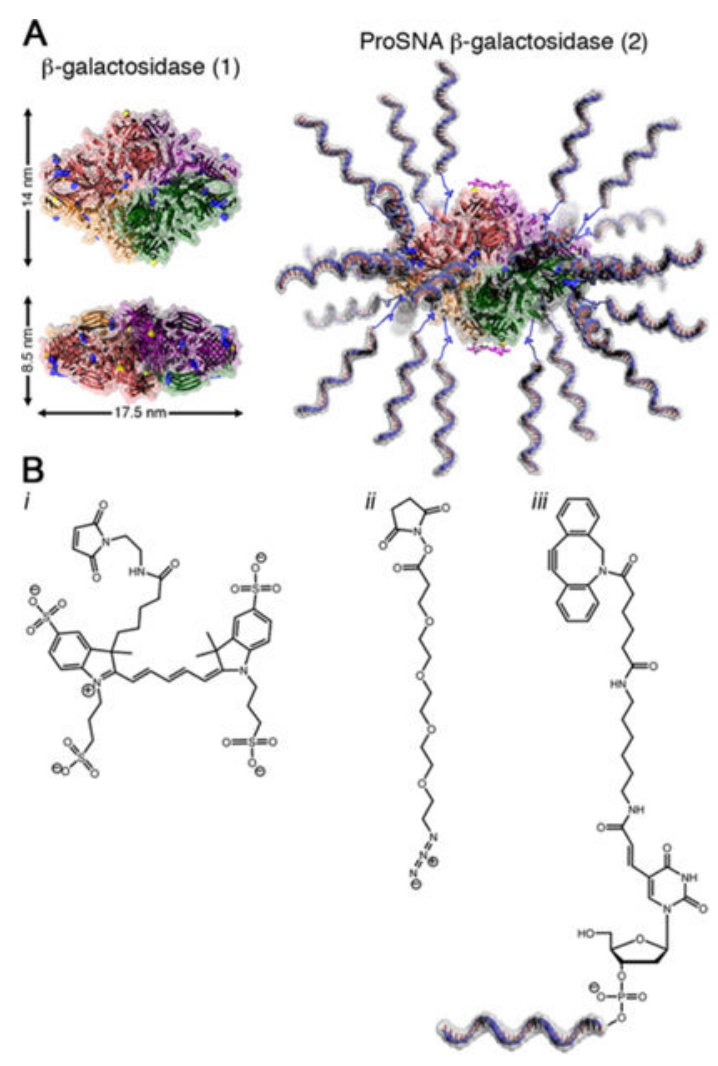

Figure 1.

(A) Cartoon representation of $\beta$-gal before (left) and after (right) functionalization with DNA. The representation was adapted from PDB ID $1 \mathrm{BGL} .{ }^{40}$ Surface lysines and cysteines are represented as blue and yellow sticks, respectively. AF fluorophores covalently attached to the surface of the protein are shown as magenta sticks. (B) Molecules used for modification of $\beta$-gal with fluorophores (i), azides (ii), and DNA (iii). 

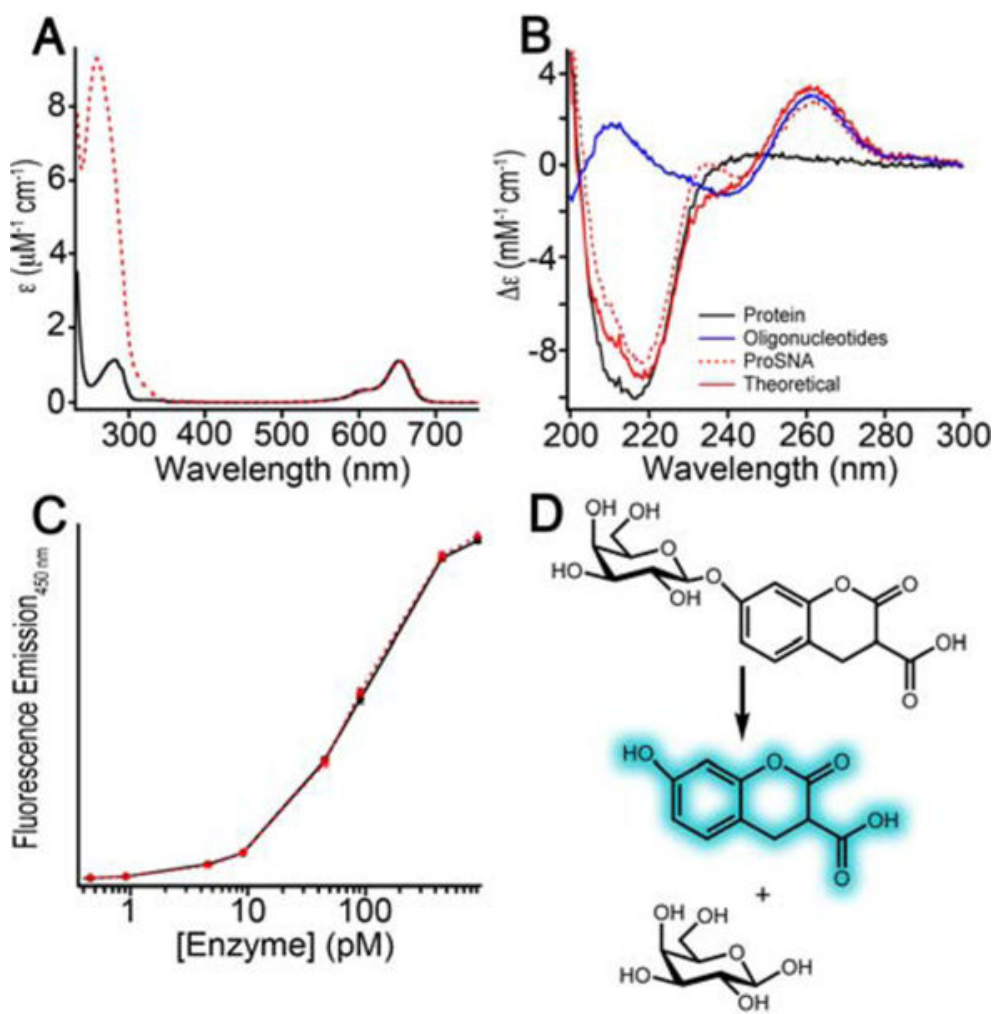

Figure 2.

Characterization of the structure and catalytic functionality of native (solid black traces) and ProSNA (dashed red traces) $\beta$-gal. (A) UV-vis absorbance spectra used to quantitate the functionalization of $\beta$-gal with AlexaFluor 647 and DNA. (B) CD spectra demonstrating the retention of the secondary structure of $\beta$-gal after functionalization with DNA. (C)

Fluorescence assay for determining the catalytic activity of $\beta$-gal variants based on the reaction depicted in (D). 
A

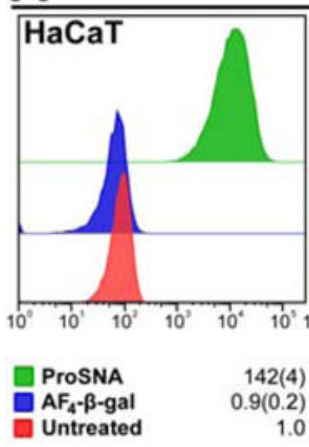

B

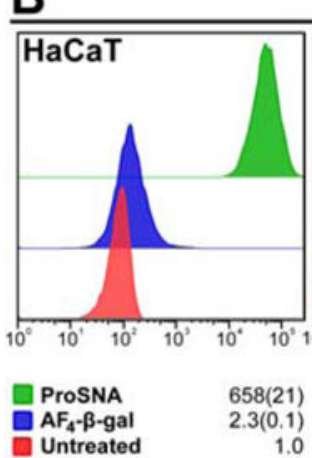

$0.1 \mathrm{nM}$

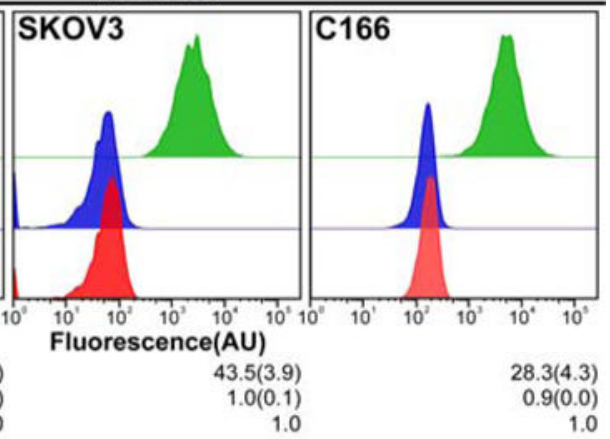

$1.0 \mathrm{nM}$

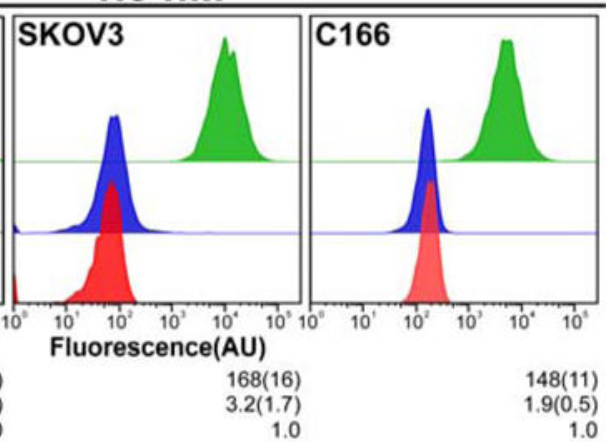

Figure 3.

Cellular uptake of native (blue) and ProSNA (green) $\beta$-gal, as determined by flow cytometry. Fluorescence was measured in $\mathrm{HaCaT}$, SKOV3, and C166 cells $12 \mathrm{~h}$ after treatment with either $0.1 \mathrm{nM}$ (top) or $1 \mathrm{nM}$ (bottom) enzyme. The fold increase over untreated cells (red) for each sample is listed below the graph with the standard deviation for $n=3$ trials in parentheses. The $y$-axis is cell count for a single trial of $>5000$ cell events. 


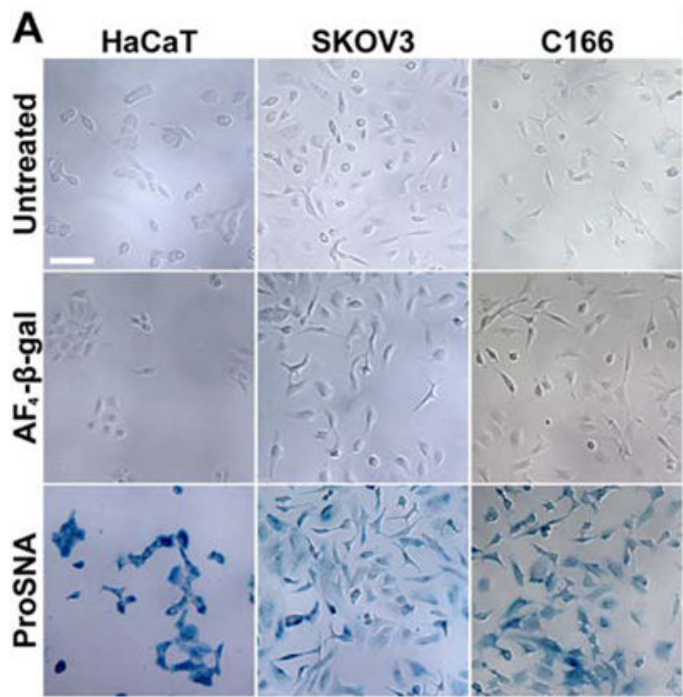

B Hoescht AF647

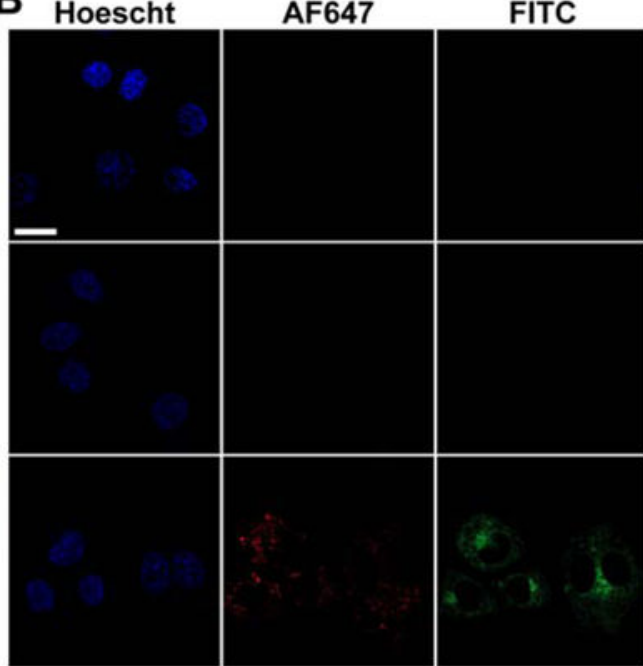

Merge

Figure 4.

Intracellular catalytic activity of native and ProSNA $\beta$-gal. (A) Light micrographs of HaCaT (left), SKOV3 (middle), and C166 (right) cells after incubation with the $\beta$-gal substrate, Xgal. The blue color apparent in cells pretreated with ProSNA $\beta$-gal results from the hydrolysis of Xgal and formation of an insoluble reaction product. Scale bar $=100 \mu \mathrm{m}$. (B) Confocal fluorescence micrographs of $\mathrm{C} 166$ cells to simultaneously monitor the intracellular location of ProSNA $\beta$-gal (AF647 channel) and the presence of fluorescein (FITC channel), which is the product of the intracellular reaction between $\mathrm{C}_{12}$-FDG and ProSNA $\beta$-gal.

Nuclei were stained with Hoechst stain to approximate the location within the cell. Scale bar $=20 \mu \mathrm{m}$. 